\title{
Rzeczownikowość a czasownikowość kategorii słowotwórczych rzeczownika w języku polskim
}

\section{Between the substantive and verb essence of word- formation category of Polish noun}

\author{
Michat Szczyszek \\ INSTYTUT FILOLOGII POLSKIEJ, UNIWERSYTET IM. ADAMA MICKIEWICZA W \\ POZNANIU UL. A. FREDRY 10, 61-701 POZNAŃ \\ szczysze@amu.edu.pl, szczyszek@tlen.pl
}

\begin{abstract}
The article has one aim: research correlation between Nisbett's conception of geography of thought and its linguistic confirmations, on the word-formation level. I analysed word-formation categories of Polish noun. Thesis about Western property of Polish derivative system (and polish thought, categorization) take the confirmation.
\end{abstract}

Keywords: system słowotwórczy polszczyzny, konceptualizacja językowa, koncepcja R. E. Nisbetta, polska wspólnota komunikatywna

\section{Wstęp}

W artykule Słowotwórcze przejawy wspólnoty komunikacyjnej (na przykładzie języka polskiego) (Szczyszek, w druku) podjąłem próbę zaadaptowania na grunt językoznawstwa (na przykładzie języka polskiego) koncepcji R. E. Nisbetta znanej z książki Geografia myślenia (Nisbett 2009). W artykule tym, w którym starałem się opisać relację między polskim systemem słowotwórczym a funkcjonowaniem polskiej wspólnoty komunikatywnej, przedstawiłem następująco koncepcję Nisbetta: „Streszczając w największym skrócie koncepcję amerykańskiego psychologa, psychologa społecznego R. E. Nisbetta, należy powiedzieć, że badacz ten obserwując społeczeństwa Zachodu ( $\mathrm{tj}$. społeczeństwa głównie Niemiec, Holandii, Belgii, Francji, Hiszpanii, Portugalii, Włoch, Anglii, USA i Kanady) oraz Dalekiego Wschodu (tj. głównie Korei Płd, Japonii, Chin, Indii), orzekł, że te pierwsze są nastawione na wyodrębnianie $\mathrm{z}$ tła konkretnych zjawisk, przedmiotów itp., natomiast te drugie - na opis kontekstu i relacji, w jakich znajdują się zjawiska względem siebie. Na poziomie językowym te różnice w postrzeganiu rzeczywistości skutkują mocną pozycją rzeczownika w językach 
Zachodu, czyli częścią mowy wyodrębniającą zjawiska $\mathrm{z}$ tła, natomiast $\mathrm{w}$ językach Dalekiego Wschodu - mocną pozycją czasownika, czyli częścią mowy opisującą relacje, w jakich znajdują się względem siebie i względem nadawcy i odbiorcy dane zjawiska (Nisbett 2009: 69-88 oraz 105-122)" (por. Szczyszek, w druku). W konkluzjach artykułu zapisałem, że na podstawie analizy polskiego systemu słowotwórczego - w ujęciu globalnym, całościowym - można stwierdzić silne jego „urzeczownikowienie”, a zatem mocną słowotwórczą, a więc w zakresie jednego ze sposobów kategoryzacji i konceptualizacji świata, tendencję prozachodnią (tu odwołując się właśnie do koncepcji Nisbetta), niemniej dostrzegalny jest „wschodni refleks” - poprzez dość liczną „populację” derywatów czasownikowych i odczasownikowych w polskim słowotwórstwie (por. Szczyszek, w druku).

W niniejszym szkicu, kontynuując rozważania z przywołanego wyżej tekstu, opiszę wyniki analiz „centrum rzeczownikowości” polskiego systemu słowotwórczego - kategorie słowotwórcze rzeczownika. Celem tego przyczynku jest analiza rzeczownikowych wartości kategorialnych i na tej podstawie określenie stopnia rzeczownikowości w opozycji do czasownikowości tych kategorii słowotwórczych, a zatem - w konsekwencji i poniekąd pośrednio funkcjonujących w języku polskim derywatów rzeczownikowych.

Tekst ten jest wstępną propozycją ustalenia charakteru polskiego systemu słowotwórczego - jego rzeczownikowości czy czasownikowości; tekst jest początkową próbą mającą $\mathrm{W}$ zamierzeniu wprowadzić wyjściowe, robocze hipotezy odnośnie do wskazanej problematyki. Próba ta i przetestowanie wyjściowych założeń są przeprowadzane na materiale języka polskiego; natomiast dalsze badania w tym zakresie winny mieć charakter porównawczy (do czego ten przyczynek jest swoistym wstępem) - np. konfrontacji polskiego systemu słowotwórczego z systemami słowotwórczymi innych języków Zachodu oraz Dalekiego Wschodu.

\section{Metoda}

Analizie poddam zbiór wartości kategorialnych przypisanych polskim kategoriom słowotwórczym rzeczownika. Na potrzeby niniejszego szkicu korzystam $\mathrm{z}$ opracowania R. Grzegorczykowej Zarys stowotwórstwa polskiego. Słowotwórstwo opisowe (Grzegorczykowa 1979), będącym - jak dotąd - jedynym pełnym opracowaniem teorii słowotwórczej, prezentującym podział całego materiału słowotwórczego na kategorie słowotwórcze (choć niepozbawionym wad i usterek, które uwzględniam, nie odnosząc się do nich w tym szkicu). Późniejsze opracowanie R. Grzegorczykowej i J. Puzyniny, w tzw. „żółtej gramatyce" (Grzegorczykowa, Puzynina 1984), jest zmodyfikowanym, doprecyzowanym - względem wcześniej wskazanego - dziełem (uwzględniającym np. m.in. strukturę argumentowo-predykatową wpisaną w parafrazę słowotwórczą derywatów), lecz z punktu widzenia niniejszego tekstu niewnoszącym nowych informacji. W części analitycznej będę się zatem opierał głównie na opracowaniu Grzegorczykowej (Grzegorczykowa 1979), posiłkując 
się - w celu ewentualnego doprecyzowania sądów (i późniejszych wniosków) „żółtą gramatyką" (Grzegorczykowa, Puzynina 1984), a w uzasadnionych wypadkach - i innymi tekstami z zakresu słowotwórstwa polskiego.

Analiza wartości kategorialnych poszczególnych kategorii słowotwórczych będzie polegała na ustaleniu dwóch parametrów: 1) określeniu, czy derywaty danej kategorii słowotwórczej wykazują relację formalną do rzeczownika, czasownika lub innej części mowy stanowiącej składnik danej wartości kategorialnej; 2) określeniu, czy derywaty danej kategorii słowotwórczej wykazują relację semantyczną do znaczeń uabstrakcyjnionych (skategoryzowanych właśnie) rzeczownika, czasownika lub innej części mowy stanowiącej składnik danej wartości kategorialnej. Na podstawie odpowiedzi na tak sformułowane pytania badawcze, będę formułował wnioski końcowe tego przyczynku.

\section{Analiza}

Renata Grzegorczykowa wyodrębniła w całym zasobie polskich derywatów rzeczownikowych 14 kategorii słowotwórczych o odmiennych - każda od każdej - wartościach kategorialnych. Są to (por. Grzegorczykowa 1979 : 29-57):

a. nazwy czynności o wartości kategorialnej: 'wykonywanie czynności' (co inaczej można sformułować: 'to, że się wykonuje czynność wskazaną w parafrazie słowotwórczej');

b. nazwy cech abstrakcyjnych o wartości kategorialnej 'bycie jakimś' (co inaczej można sformułować: 'bycie takim, jakim wskazuje przymiotnik w parafrazie słowotwórczej’);

c. nazwy wykonawców czynności o wartości kategorialnej: 'ten, kto wykonuje daną czynność (wskazaną przez czasownik w parafrazie słowotwórczej)' lub 'ten, kto wykonuje jakąś czynność na obiektem (wskazanym przez rzeczownik w parafrazie słowotwórczej)' (por. też Walczak-Mikołajczakowa 2000);

d. nazwy narzędzi o wartości kategorialnej: 'to, co służy do wykonywania czynności (wskazanej przez czasownik w parafrazie słowotwórczej)';

e. nazwy obiektów i wytworów czynności o wartości kategorialnej: 'to, co jest wynikiem działania jakiejś czynności (wskazanej przez czasownik w parafrazie słowotwórczej)' lub 'to, co jest przeznaczone do bycia obiektem czynności (wskazanej przez czasownik w parafrazie słowotwórczej)';

f. nazwy nosicieli cech o wartości kategorialnej: 'ten, kto lub to, co charakteryzuje się daną cechą (wskazaną przez rzeczownik lub przymiotnik w parafrazie słowotwórczej)';

g. nazwy miejsc o wartości kategorialnej: 'to, gdzie odbywa się jakaś czynność (wskazana przez czasownik w parafrazie słowotwórczej)' lub 'miejsce, gdzie znajdują się jakieś przedmioty (wskazane przez rzeczownik w parafrazie słowotwórczej)', lub 'miejsce charakteryzujące się czymś (wskazanym przez przymiotnik w parafrazie słowotwórczej)';

h. nazwy zbiorów o wartości kategorialnej: 'zbiór osób lub przedmiotów (wskazanych przez rzeczownik w parafrazie słowotwórczej)'; 
i. nazwy mieszkańców o wartości kategorialnej: 'ten, kto mieszka w danym miejscu (wskazanym przez rzeczownik (nazwę własną) w parafrazie słowotwórczej)';

j. nazwy pokrewieństwa o wartości kategorialnej: 'potomek osoby (wskazanej przez rzeczownik (pospolity lub nazwę własną) w parafrazie słowotwórczej)';

k. nazwy żeńskie o wartości kategorialnej: 'nazwy kobiet utworzone od nazw męskich (wskazanych przez rzeczownik w parafrazie słowotwórczej)';

1. nazwy deminutywne o wartości kategorialnej: 'ten lub to, co jest mniejsze od przedmiotów w standardowych rozmiarach (wskazanych przez rzeczownik w parafrazie słowotwórczej' lub 'ten lub to, w stosunku do czego wyrażane są emocje pozytywne lub negatywne (osoba lub przedmiot wskazane przez rzeczownik w parafrazie słowotwórczej');

m. nazwy augmentatywne i ekspresywne o wartości kategorialnej: 'ten lub to, co jest większe od przedmiotów w standardowych rozmiarach (wskazanych przez rzeczownik w parafrazie słowotwórczej' lub 'ten lub to, w stosunku do czego wyrażane są emocje pozytywne lub negatywne (osoba lub przedmiot wskazane przez rzeczownik w parafrazie słowotwórczej)';

n. nazwy istot młodych o wartości kategorialnej: 'młoda, niedoświadczona w danym zawodzie osoba, aplikant zawodu wskazanego przez rzeczownik w podstawie słowotwórczej' lub 'młode zwierzę rasy czy gatunku wskazanego przez rzeczownik w parafrazie słowotwórczej'.

Kategorie słowotwórcze $a$. oraz $b$. R. Grzegorczykowa określiła jako transpozycyjne, tj. derywaty mają dokładnie takie samo znaczenie, jak ich podstawy słowotwórcze.

Kategorie słowotwórcze od $c$. do $j$. R. Grzegorczykowa określiła jako mutacyjne, tj. derywaty oznaczają zupełnie inne, odrębne zjawiska od zjawisk nazywanych przez podstawy słowotwórcze.

Kategorie słowotwórcze od $k$. do $n$. R. Grzegorczykowa określiła jako modyfikacyjne, tj. derywaty doprecyzowują jedynie znaczenie swoich podstaw, nie nazywając nowych zjawisk rzeczywistości pozajęzykowej.

Dwie pierwsze kategorie słowotwórcze nie nastręczają problemów interpretacyjnych. Pierwsza z nich - nazwy czynności - odnosi się zarówno w płaszczyźnie formalnej, jak i semantycznej (głównie) do czasownika (predykatu). Jest więc to - przede wszystkim - kategoria uczasownikowiona, choć można odnaleźć także przykłady derywatów mających pośrednie odniesienie do rzeczownika, np. matkowanie $\leftarrow$ matkować $\leftarrow$ matka, meblowanie $\leftarrow$ meblować $\leftarrow$ mebel. $\mathrm{Z}$ tego względu można by więc uznać tę kategorię za uczasownikowioną oraz - $\mathrm{w}$ znacznie mniejszej skali - za pośrednio urzeczownikowioną. Druga $\mathrm{z}$ kategorii transpozycyjnych - nazwy cech abstrakcyjnych - odnosi się do przymiotnika w obu płaszczyznach. Tutaj komentarza wymaga jedynie typ podstawowego przymiotnika: są to zazwyczaj przymiotniki jakościowe, określające cechy immamentne określanych rzeczowników, np. młodość $\leftarrow$ młody; sporadycznie w podstawie słowotwórczej może pojawić się przymiotnik relacyjny, np. dzietność $\leftarrow$ dzietny $\leftarrow$ dziecko. 
Można zatem tę kategorię słowotwórczą określić jako kategorię pośrednio urzeczownikowioną, tzn. poprzez relacje słowotwórcze (omówione powyżej) oraz relacje składniowe - przymiotniki składniowo (i semantycznie) najczęściej łączą się $\mathrm{z}$ rzeczownikami, stanowiąc wraz $\mathrm{z}$ nimi grupę nominalną wypowiedzenia (zdania); jest to prymarna funkcja składniowa przymiotników (por. Bańko 2011).

Najwięcej problemów interpretacyjnych pojawia się $\mathrm{W}$ grupie kategorii mutacyjnych (od $c$. do $j$.), ponieważ jest to grupa niejednorodna $\mathrm{z}$ punktu widzenia problematyki podjętej $\mathrm{w}$ niniejszymo artykule. W każdej kategorii relacja formalna i semantyczna generalnie się pokrywa (z drobnymi, statystycznie nieistotnymi wyjątkami, np. oczkowicz - 'kierowca, który w ciągu roku uzbierał 21 punktów karnych'; tu formalna relacja jest rzeczownikowa, natomiast semantyczna - odnosi się do bardziej skomplikowanej struktury frazematycznej gra $w$ oczko). Do kategorii czysto urzeczownikowionych można zaliczyć 4 spośród kategorii mutacyjnych: f. nazwy nosicieli cech, kategoria ta jednocześnie może być określona jako pośrednio urzeczownikowiona ze względu na relację części derywatów do przymiotnika, $h$. nazwy zbiorów, i. nazwy mieszkańców oraz $j$. nazwy pokrewieństwa. Do kategorii czysto uczasownikowionych zaliczyć należy 2 kategorie: $d$. nazwy narzędzi oraz e. nazwy obiektów $i$ wytworów czynności. Kategorie pośrednie, mające charakter zarówno czasownikowy, jak i rzeczownikowy, stanowią dwie z dotąd nie wskazanych kategorii mutacyjnych: $c$. nazwy wykonawców czynności oraz g. nazwy miejsc. Kategoria nazwy wykonawców czynności rozpada się na dwie grupy: uczasownikowioną, o większej potencjalności, ponieważ formanty tworzące derywaty odczasownikowe tej kategorii oznaczają się wysoką lub rosnącą produktywnością (rosnącą produktywność obserwować można zwłaszcza wśród formantów obcego pochodzenia zapożyczonych przez polszczyznę w ostatnich dwudziestu latach (por. Waszakowa 2005)), np. typy słowotwórcze -yciel, -er; druga grupa jest urzeczownikowiona i charakteryzuje się niższą produktywnością formantów, jednakże liczba derywatów utworzonych tymi formantami może być w tekstach znaczna, np. typ słowotwórczy -arz. Natomiast kategoria słowotwórcza nazwy miejsc jest najbardziej skomplikowana, gdyż derywaty tej kategorii wykazują relację do czasowników, rzeczowników i przymiotników. Formanty tworzące derywaty odczasownikowe i odrzeczownikowe charakteryzują się stosunkowo wysoką produktywnością (np. typ na -arnia: palarnia czy wózkarnia); natomiast formanty tworzące derywaty odprzymiotnikowe cechują się niską produktywnością (np. równina). Omawiana kategoria jest zatem uczasownikowiona, urzeczownikowiona i pośrednio urzeczownikowiona.

Najłatwiej można określić relację formalną i semantyczną między derywatem a podstawą w grupie kategorii słowotwórczych modyfikacyjnych (kategorie od $k$. do $n$.). I tutaj obie relacje - formalna i semantyczna - się pokrywają i odnoszą tylko i wyłącznie do rzeczownika. Można więc powiedzieć z całą pewnością, że te 4 kategorie słowotwórcze charakteryzują się rzeczownikową relacją formalną i semantyczną. Inaczej mówiąc - te 4 kategorie są urzeczownikowione.

Po zliczeniu kategorii urzeczownikowionych i uczasownikowionych, uzyskałem następujące dane: 
- liczba kategorii uczasownikowionych: 3,

- liczba kategorii urzeczownikowionych (z podgrupą kategorii pośrednio urzeczownikowionych): $10-$ wliczając $\mathrm{W}$ to 1 kategorię odprzymiotnikową (czyli też: pośrednio urzeczownikowioną),

- liczba kategorii mieszanych: 2 - obie kategorie rozpadają się na dwie podgrupy: uczasownikowioną i urzeczownikowioną (włączając tu pośrednio urzeczownikowioną).

Dokładniej warto także przeanalizować grupę kategorii mutacyjnych, czyli tych, których derywaty opisują zupełnie nowe zjawiska rzeczywistości pozajęzykowej. Są to zatem kategorie najbardziej wpływające na kategoryzację świata, kształt jego konceptualizacji. Wśród 8 mutacyjnych kategorii słowotwórczych 4 są czysto urzeczownikowione, 1 - uczasownikowione, 3 kolejne - mają właśnie charakter mieszany.

\section{Wnioski}

Powyższe analizy zostały przeprowadzone na podstawie danych systemowych, tzn. pochodzących $\mathrm{z}$ opracowań polskiego systemu słowotwórczego, a zatem wnioski można formułować i odnosić tylko i wyłącznie do poziomu systemowego.

$\mathrm{Na}$ poziomie systemu widać wyraźnie rzeczownikowy charakter rzeczownikowych kategorii słowotwórczych. Wartości kategorialne analizowanych tu kategorii mają $\mathrm{w}$ przeważającej większości charakter odrzeczownikowy, tzn. wykazują występowanie relacji formalnej i semantycznej odniesionych do rzeczownika. Zatem derywaty kwalifikowane do tych kategorii słowotwórczych są wyraźnie, w przeważającej większości, urzeczownikowione poprzez odwołanie się $\mathrm{w}$ podstawach słowotwórczych do rzeczownika. Pojawianie się w podstawach słowotwórczych przymiotników - czy niekiedy niektórych czasowników odrzeczownikowych - świadczy o pośrednio urzeczownikowionym charakterze danej kategorii słowotwórczej czy podgrupy w danej kategorii. Dodatkowym argumentem przemawiającym za rzeczownikowym charakterem rzeczownikowych kategorii słowotwórczych jest fakt, że derywaty do nich kwalifikowane, a motywowane rzeczownikiem, bardzo często są nazwami osób, co jest oczywistym efektem antropocentryzmu językowego (por. np. Kita, Polański 2002; Anusiewicz, Skawiński 1998), dostarczającego tu dodatkowego argumentu za rzeczownikowym charakterem analizowanych tu kategorii słowotwórczych.

Dwie z analizowanych uczasownikowionych kategorii słowotwórczych to nazwy narzędzi oraz wytworów, a więc zjawisk dalekich od epicentrum antropocentryzmu językowego.

Potwierdza się zatem konkluzja, którą wyraziłem w swoim poprzednim artykule na temat koncepcji Nisbetta i możliwości jej adaptacji na grunt językoznawczy (Szczyszek, w druku). Okazuje się ponownie, że w polskim systemie słowotwórczym uwidaczniają się wyraźnie elementy konceptualizacji świata typowe dla kultury Zachodu. Są, tkwią w nim (w polskim systemie 
słowotwórczym) i składniki typowe dla kultury Wchodu, jednakże - co można precyzyjniej stwierdzić dzięki analizom przeprowadzonym na potrzeby niniejszego szkicu - są one w mniejszości, a proporcja, za pomocą której można to wyrazić, wynosi 10:5 na korzyść rzeczownikowości omawianych tu kategorii słowotwórczych. Zatem - słowotwórstwo polskiego rzeczownika cechuje się właściwościami kategoryzacji świata typowymi dla kultury Zachodu.

Rzeczownikowy charakter polskiego słowotwórstwa, a dokładniej rzecz ujmując: zwiększający się $\mathrm{w}$ planie historycznojęzykowym udział rzeczownikowych podstaw słowotwórczych $\mathrm{w}$ tworzeniu derywatów na przestrzeni do doby staropolskiej do współczesności pokazała Krystyna Kleszczowa (Kleszczowa 2010). Autorka wyraźnie bowiem stwierdziła, przeprowadzając porównawcze analizy historycznojęzykowe polskiego materiału słowotwórczego $\mathrm{z}$ oddalonych od siebie epok rozwojowych, że udział rzeczowników jako podstaw, jak i - w konsekwencji - sama rzeczownikowość polskiego słowotwórstwa nieustannie się zwiększają, aż do osiągnięcia stanu dzisiejszego. Można zatem stwierdzić, że tezy niniejszego szkicu (opracowywanego z perspektywy językowo-kulturowej) korespondują z wnioskami artykułu K. Kleszczowej (uzasadnianymi analizami historycznojęzykowymi).

Dalsze badania nad przejawami rzeczownikowości czy czasownikowości polskiego słowotwórstwa - i dalsze weryfikowanie koncepcji Nisbetta w odniesieniu do właściwości polskiej wspólnoty komunikatywnej (na podstawie potencjału słowotwórczego polskiego kodu wspólnotowego) - należałoby przeprowadzać w czterech aspektach: 1) analizy charakteru rzeczownikowych podstaw ze względu na konkretny lub abstrakcyjny ich charakter (rzeczowniki abstrakcyjne (np. kontrola, recenzja) mają bardziej „czasownikowy” charakter niż rzeczowniki konkretne; może się wiec okazać, że i przy rzeczownikowej podstawie słowotwórczej derywat od rzeczownika abstrakcyjnego będzie wykazywał właściwości „uczasownikowienia”); 2) analizy słowotwórstwa innych części mowy, a więc pozostałych kategorii (i typów) słowotwórczych; 3) analizy tekstów, tj. derywatów $w$ nich tkwiących, czyli faktycznych realizacji systemowych modeli słowotwórczych; 4) analizy porównawczej polskiego systemu słowotwórczego z systemem słowotwórczym jednego lub kilku języków Zachodu oraz Dalekiego Wschodu. 


\section{Bibliografia}

Anusiewicz, J., Skawiński, J. 1998. Słownik polszczyzny potocznej. Warszawa-Wrocław: Państwowe Wydawnictwo Naukowe

Bańko, M. 2011. Wykłady z polskiej fleksji. Warszawa: Państwowe Wydawnictwo Naukowe

Grzegorczykowa, R. 1979. Zarys słowotwórstwa polskiego. Słowotwórstwo opisowe. Warszawa: Państwowe Wydawnictwo Naukowe

Grzegorczykowa, R., Puzynina, J. 1984. Słowotwórstwo rzeczowników. W: Urbańczyk, S. (red.). 1984. Gramatyka współczesnego języka polskiego. t. II: Grzegorczykowa, R., Laskowski, R., Wróbel., H. 1984. Morfologia. Warszawa: Państwowe Wydawnictwo Naukowe, s. 332-407

Kita, M., Polański, E. 2002. Człowiek w krainie słów. Słownik tematyczny języka polskiego. Warszawa: Wydawnictwo Edukacyjne GRAFPUNKT

Kleszczowa, K. 2010. Historycznie o podstawach słowotwórczych polskich rzeczowników. LingVaria nr 2, s. 1-9

Nisbett, R.E. 2009. Geografia myślenia. Dlaczego ludzie Wschodu i Zachodu myślą inaczej, przekł. E. Wojtych. Sopot: Wydawnictwo „Smak Słowa”

Szczyszek M. (w druku), Słowotwórcze przejawy wspólnoty komunikacyjnej (na przykładzie języka polskiego)

Walczak-Mikołajczakowa, M., 2000. Słowotwórstwo agentywnych nazw osobowych w języku polskim, rosyjskim i bułgarskim. Poznań: Wydawnictwo Poznańskiego Towarzystwa Przyjaciół Nauk

Waszakowa, K. 2005. Przejawy internacjonalizacji w słowotwórstwie współczesnej polszczyzny. Warszawa: Wydawnictwa Uniwersytetu Warszawskiego 